\title{
EVALUATION OF COMPOSTING PROCESS AND QUALITY OF COMPOST FROM COFFEE BY-PRODUCTS (COFFEE HUSK \& PULP) *Henok Kassa ${ }^{1}$, Hammed Suliman ${ }^{2}$ and Tenaw Workayew ${ }^{3}$
}

\author{
DOI: http://dx.doi.org/10.4314/ejesm.v4i4.2
}

\begin{abstract}
Coffee pulp and husk are the main by-products generated by the coffee processing station and are disposed into arable land and surface water. Due to the contribution of these by-products to environmental pollution, environmentally friendly disposal methods are necessary. Therefore, composting as environmental friendly option for utilization of coffee by-products is important. The objectives of the study were to assess the properties of coffee by-products compost and analyzing changes in physico-chemical properties during process of composting. To this end, (coffee husk + pulp) (control), (coffee husk + pulp + cow dung), (coffee husk + pulp + Millettia ferruginea), (coffee husk + pulp + cow dung + Millettia ferruginea), (coffee husk + pulp + effective microorganism) were used to prepare compost. The experiment was laid in RCBD (5x3). The physico-chemical parameters were determined for all the treatments at 25, 45 and 70 days of composting. The level of $\mathrm{pH}$ in coffee by-products compost amended with Millettia ferruginea were highly significant $(P<0.0001)$ as compared to coffee by-products compost amended with cow dung and effective microorganism alone. The level of $N$ and Exch. $K$ in coffee by-products compost amended with cow dung and Millettia ferruginea were highly significant $(P<0.0001)$ as compared to the control and coffee by-products compost amended with cow dung and effective microorganism alone. The level of total $N, O M$, and $C / N$ ratio in 25 day of composting were highly significant $(p<0.0001)$ as compared to 70 day of composting. The physico-chemical parameter in different time of composting indicates that, composting coffee by-products compost up to 70 day were important to acquire quality compost. Comparison of experimental results proved that coffee byproducts compost amended with Millettia ferruginea and cow dung was better than other treatments for quality compost preparation. It is better to amend the coffee by-products with organic material before composting to improve the quality of the compost.
\end{abstract}

Received September $2^{\text {nd }} 2011$; accepted November $21^{\text {st }} 2011$

Key words: Coffee by products, Composting, Quality compost

\section{Introduction}

Ethiopia is the primary center of origin and genetic diversity of arabica coffee (Coffea arabica L.). Coffee farming systems in Ethiopia are conventionally divided into four categories: forest coffee, semi-forest coffee, garden coffee and modern plantation (Paulos and Demil, 2000). The production capacity of the country, which is currently estimated at 301,000 tons, is targeted to increase to 419,000 tons by the end of 2010 (MoFED, 2006).

Coffee is processed by two widely known methods, dry and wet coffee processing. Seventy percent of the coffee exported from Ethiopia is as

${ }^{I}$ Environmental Science Program, Ambo University, Mizan Teferi, Ethiopia

Corresponding author email: henokassa@gmail.com

${ }^{2}$ Environmental Science Program, Addis Ababa University

Addis Ababa, Ethiopia.

${ }^{3}$ Hawassa Research Center, Hawassa sun-dried while the rest $(30 \%)$ as wet processed coffee (washed) (FDRE, 2006).

Coffee pulp and husk occurs after picking of coffee cherries, the fruit has to undergo several processing steps in order to remove the outer parts of the fruit. The by-product of the wet processing of coffee particularly coffee processing effluent and discharge from the composting pulp can cause considerable pollution of water courses (Anon., 1991), which are mainly the source of water not only for coffee processing but also for domestic and agricultural requirements. Coffee pulp and husk are the main by-products generated by the coffee processing units and are disposed into arable land and surface water. Due to the presence of 
polyphenols which are considered as antinutritional and phytotoxic substances such as caffeine, tannin, organic acids which restricts its larger extent uses in agriculture and imposing problem on the environment (Bressani, 1979). However, these wastes contain high concentrations of biodegradable organic compounds and minerals of plant origin which can be better utilized by composting with other organic materials.

\section{Material and Methods Study Area}

The Experiment was conducted in Hawassa Agricultural Research Center. Hawassa is located in $7^{0} 3^{\prime} \mathrm{N}$ of latitude and $38^{\circ} 28^{\prime} \mathrm{E}$ longitude and with an altitude of 1700-1750 m (AARC, 2004). The rainfall is bimodal with a long term mean rainfall of $1021 \mathrm{~mm}$, and about $36.4 \%$ is received from February to May and $51.3 \%$ is received from June to September. The long term mean maximum and minimum temperatures in May vary from 24 to $27{ }^{\circ} \mathrm{C}$ and in September vary from 12.8 to 13.8 ${ }^{0} \mathrm{C}$. The soil of the experimental site was loam (AARC, 2004).

\section{Composting material and collection}

The basic organic raw materials used for composting were coffee husk $(\mathrm{CH})$, coffee pulp (CP), and other additives like parts of leguminous trees foliage of Millettia ferruginea, cow dung, and effective microorganism (EM). Coffee pulp and coffee husk were collected from Yergalem wet and dry coffee processing station. Cow dung was collected from a dairy farm of Hawassa Agricultural Research Center. Leguminous tree foliage of Millettia ferruginea was collected from Hawassa Agricultural College. Effective microorganism was procured from Addis Ababa (Ethiopia agricultural research organization). Finally the common bulking agent top soil was taken from Hawassa Agricultural Research center.

\section{Preparation of composting material}

Based on the treatments, an individual heap having the size of $1 \mathrm{~m}$ length, $1 \mathrm{~m}$ width and $1 \mathrm{~m}$ height was prepared. The composting material was piled up in different thickness and set up on the earth's surface. The heap was shuffled after one week in order to enhance the composting process by blending and breaking up the composting materials (Harold et al., 1994). The most efficient method of composting coffee husk and pulp has been described by Adams and Dougan (1980 and
1981). Aerobic windrow composting method was used for composting. The composting method involved mixing organic amendment with the respective "pure" by-products. The top soil was added to each layer to aid the composting process.

The ground area used for compost heaps was $\left(1 \mathrm{~m}^{3}\right)$, based on the recommendations of the Henry Doubleday Research Association (HDRA), (2001) and with some modifications in basic layering sequence.

\section{Experimental Treatments}

The experiment was laid in Randomized Complete Block Design (5x3), using the following treatments.

Treatment 1 (T1) (Control): Coffee by- products (coffee husk and pulp)

Treatment 2 (T2): Coffee by-products plus cow dung

Treatment 3 (T3): Coffee by-products plus leaf of Millettia ferruginea

Treatment 4 (T4): Coffee by-products plus leaf of Millettia ferruginea plus cow dung

Treatment 5 (T5): Coffee by-products plus Effective Microorganism (EM)

The top soil was added to each treatment to aid the composting process.

\section{Result and Discussion}

Changes in Temperature, pH, Electrical conductivity and Cation exchange capacity during Composting

Generally, it was observed that there were statistically significant differences between temperature changes of the $\mathrm{T} 1$ (control) and other treatment (T4 and T3) at $\mathrm{p}<0.0045$. According to Epstein (1997) and Strom (1985), this variation in temperature is one of the most important parameters that reflect the microbiological activity in the composting process.

The rise in temperature in D25 and D45 might be due to heat generated as the microorganisms decompose organic material. Study by Vashi and Shah (2003) on cocomposting of municipal solid waste with sewage Sludge; Taiwo and Oso (2004) on composting of MSW and Anandavalli et al. (1998) on recycling of banana Pseudo stem compost also showed temperature decrement as the composting process proceeds.

The higher $\mathrm{pH}$ was recorded in $\mathrm{T} 3$. This might be due to production ammonia during 
decomposition of organic nitrogen by microorganism or might also as a result of release of basic cations from the mineralization of organic matter. A study by Bishop and Godfrey (1983) showed that the rise in $\mathrm{pH}$ was induced due to the production of ammonia during ammonification and mineralization of organic nitrogen as a result of microbial activities.

The highest $\mathrm{pH}$ in D25 and D45 might be due to production of ammonia during ammonification and mineralization of organic nitrogen as a result of microbial activities in active composting time (between D25 and D45) of composting.

The higher CEC was recorded in T4. This might be due to release of elements (humification) from organic material as result of decomposition. The higher the CEC of the compost, the greater the ability of the particles to retain cations (Harada and Inoko, 1980).

The higher CEC was recorded in D70. This might be due to increases in release of elements (humification) from organic material as composting process proceeds. The CEC of coffee husk compost increased during composting, due to increase in material bearing a negative charge as maturity progresses (Harada and Inoko, 1980).

\section{Changes in Organic Matter and Carbon/Nitrogen ratio during composting}

The lower organic matter was recorded in T4. This might be due to the presence of additional organic amendment. The presence of additional organic amendment (Cow dung, Millettia ferruginea, in $\mathrm{T} 4$ as compared to the $\mathrm{T} 1$ (control) might balance the nutrient $(\mathrm{C}: \mathrm{N})$ ratio and creating suitable condition for microbial activity. This attributes for accelerated decomposition and conversion of organic matter into carbon dioxide, energy and stable compounds. In addition, when these results were compared with the quality compost used in the countries such as Dutch, Belgium \& Italy that is $>20 \%$, all the compost have a mean value greater than 20, which meets the requirements of these countries standards.

Generally the organic matter content at different composting time decreases from $42.9 \%$ in D25 to $31.41 \%$ in D45 to $23.56 \%$ in D70. Similarly, Anandavalli et al. (1998); FFTC (2007); Greenway and Song (2002) confirmed the reduction of organic matter content as composting process proceeds/ progresses.
The low C:N in T4 might be due to the presence of different organic amendments (Cow dung and Millettia ferruginea). This might results suitable condition and balance nutrient $(\mathrm{C}: \mathrm{N})$ ratio for microbial activity. Similarly, Chane (1999) indicated that the mineralization rates of organic carbon and nitrogen varied widely among the coffee husk and pulp examined. The amount and composition of organic matter in the by-product influenced the variation. Except T1 (control), the $\mathrm{C} / \mathrm{N}$ ratio of all treatments were in agreement with the compost quality standards used in countries such as Dutch, Belgium and Italy $(<18)$. Similarly, the mean C:N ratio of all treatments were within the range of the Ethiopian Federal EPA guidelines that recommended the $\mathrm{C} / \mathrm{N}$ ratio of good quality compost to have a final $\mathrm{C}$ : $\mathrm{N}$ ratio of 29:1 or less (EFEPA, 2004).

Generally the $\mathrm{C}: \mathrm{N}$ ration decrease at different time of composting from 16.82 in D25 to 14.77 in D45 to 11.52 in D70. The purpose of composting is to narrow the $\mathrm{C} / \mathrm{N}$ ratio.

\section{Changes in Major nutrients during composting}

The higher nitrogen was recorded in $\mathrm{T} 4$ and T3. This might be due to the difference in nitrogen content of the feedstock, which $\mathrm{T} 4$ and T3 contains additional nitrogen rich amendment like Millettia ferruginea (2.85\%) nitrogen in composting material. This result is in agreement with compost quality standards for compost used in agriculture in Switzerland $(>1 \%)$ and India $(>0.8 \%)$. Besides, the result is in agreement with the recommendations of Barker (1997) who stated that to report compost as having fertilizing capabilities and for it to be used in agriculture the total $\mathrm{N}$ content must be over $1 \%$ dry weight.

The nitrogen content decreases at different composting time from $1.45 \%$ in D25 to $1.21 \%$ in $\mathrm{D} 45$ to $1.15 \%$ in D70. This might be due decrease of nitrogen by volatilization of gaseous ammonia as composting process progresses/proceeds. The reduction in Total $\mathrm{N}$ as composting proceeds is also reported by Mahimairaja et al. (1994) on the study of losses and transformation of nitrogen during composting of poultry manure with different amendments.

The higher available phosphorous was recorded in $\mathrm{T} 4$ and $\mathrm{T} 2$. This might be due to the release of available phosphorous during decomposition of organic phosphorous. Most of 
the $\mathrm{p}$ in organic material is held in organic complex (Rechcigl and Mackinnon 1997).

The available phosphorous content increases from $167.1 \mathrm{ppm}$ in D25 to $192.9 \mathrm{ppm}$ in D45 to 205.9 ppm in D70. This might be due to decomposition of organic phosphorous when composting process proceeds. This attributes the release of available phosphorous as composting proceeds. Study by Warman and Termeer (1996) on racetrack manure, grass clippings and sewage sludge reported that $\mathrm{P}$ is not lost by volatilization during the composting process, but $\mathrm{P}$ concentration might increase as composting proceeds.

The higher exchangeable potassium content was recorded in T4 and T3. This might be due to high decomposition of raw composting material. Study by Chane (1999) on composting of coffee by-product indicated that the increase in $\mathrm{K}$ content in compost from coffee husk was due to decomposition.

The higher exchangeable potassium was recorded in D45. This might be due high decomposition of raw composting material in D45, which D45 was time of active composting (thermophilic period).

\section{Conclusions and Recommendations}

Compost heap that contained additional organic amendments exhibited higher temperature. The longer active composting time (thermophilic period) indicates high decomposition of organic matter. The decrease in compost heap temperature to ambient temperature at late stage of composting indicates the decrease in the availability of biodegradable substrate in the composting heap. Since the $\mathrm{pH}$ of the compost was more than 8 in different compost, using this compost to amend acid soil is crucial rather than using chemicals/ lime for amending the acidity. Laboratory analysis of compost confirmed that addition of organic amendment in coffee byproducts compost increases the cation exchange capacity (CEC), nitrogen level, available phosphorous and exchangeable potassium. But reduces the $\mathrm{C}: \mathrm{N}$ ratio and organic matter content of the compost as compared to control. Generally, composting coffee by-products in $(60 \%$ coffee pulp, 30\% coffee husk, 20\% cow dung, 10\% Millettia ferruginea) proportion was the best combination to enhance the quality (physicochemical property) of the compost. Composting coffee by-products up to 70 day was important to acquire quality compost. Which physicochemically characterized by lower temperature equal to ambient temperature, medium moisture, low $\mathrm{pH}$, high $\mathrm{CEC}$, medium $\mathrm{N}$, high available phosphorous, medium exchangeable $\mathrm{K}$, low organic matter, and low $\mathrm{C} / \mathrm{N}$ ratio.. It is better to amend the coffee by-products with organic material before composting to improve the quality (physico-chemical property) of the compost. It is better to compost coffee by-products up to 70 day to acquire quality compost.

\section{References}

Awassa Agricultutal Research Center (AARC). (2004). Annual report bulletin. Awassa. pp.25-26.

Adams, M.R. and Dougan J. (1980). Microbiological method for the disposal and utilization of coffee processing wastes. ASIC, 9th Colloque, Londres, 325-333.

Adams, M.R. and Dougan J. (1981). Biological management of coffee processing wastes. Tropical Science, 23:177 - 196.

Anandavalli, D.; Ramaswami, P. and Hameed, S. (1998). Recycling of Banana Pseudo stem as compost. J.Ecotoxicol.Environ.Monit.,80:191194.

Anon. (1991). Recirculation of water combined with land treatment as biotic indicators of environmental quality. pp. 647-667. In F.R. Hauer and G.A. Lamberti (ed.) Methods in stream ecology. Academic Press, San Diego, CA.

Barker, A.V. (1997). Composition and Uses of Compost, Agrcultural Uses of By-Products and Wastes ASC Symposium Series, American Chemical Society, 668: 140-162.

Bishop, P. and Godfrey, C. (1983). Nitrogen transformations during sludge composting. Biocycle. 24:34 -39.

Bressani, R. (1979). Anti-physiological factor in coffee pulp. Coffee pulp: composition, technology and utilization. IDRC. Publ. 108e:83-88.

Chane, A. (1999). Management of Coffee processing by-products for improved and sustainable Coffee production in Ethiopia, $\mathrm{PhD}$ dissertation, University of Giessen, Germany.

Epstein, E. (1997). Trace elements, heavy metals and micronutrients. P. 137-170. In: E.Epstein 
(ed.). The science of composting. Technomic Publ., Lancaster, PA. Ethiopia Federal Environmental Protection Authority (EFEPA). (2004). Guide Lines on composting. Addis Ababa, Ethiopia.

Federal Democratic Republic of Ethiopia (FDRE). (2006). Unpublished Statistics. Addis Ababa: Federal Democratic Republic of Ethiopia, Ministry of Agriculture and Rural Development. Coffee, Tea, Spices and Cotton Marketing Department. Food and Fertilizer Technology Center (FFTC). (2007). What happens during Composting? Taipei, Taiwan.

Greenway, G. and Song, Q. (2002). Heavy metal speciation in the composting process. J.Environ.Monit:4:300-305.

Harada, Y. and Inoka, A. (1980). Relationship between cation exchange capacity and degree of maturity of city refuse composts. Soil sci. Plant Nutri., 26:353-362.

Harold, D., Curtis, P. and Roy, M. (1994). Nursery Management Administration and Culture. $3^{\text {rd }}$ ed. Prentice Hall, Inc. USA. pp.437-453.

The Henry Doubleday Research Association (HDRA). The Organic Organization. (2001). Composting in the Tropics $\underline{\Pi}$. Ryton Organic Gardens Coventry, United Kingdom. HDRA publishing.

www.gardenorganic.org.uk/pdfs/internationalcompost pp/202.pdf. Accessed in 3/9/2009. Ambo University.

Mahimairaja, S., Bolan, N., Hedley, M. and Macgregor, A. (1994). Losses and transformation of poultry manure with different amendments: An incubation Experiment. Bioresource Technology, 47:265-273.

Ministry of Finance and Economic Development (MoFED). (2006). Ethiopia: Building on Progress A Plan for Accelerated and Sustained Development to End Poverty (PASDEP) (2005/06-2009/10).Volume I: Main Text. Addis Ababa.

Paulos, D. and Demil, T. (2000). The Need for Forest Coffee Germplasm Conservation in Ethiopia and its Significance on the Control of Coffee Berry Disease (CBD). In: Proceedings of the Workshop on the Control of Coffee Berry Disease in Ethiopia.

Rechcigl, J.E. and Mackinnon, H.C. (1997). Agricultural uses of by-product and wastes. ACS symposium series 668. Am. Chemical Soc. Washington, DC.

Strom, P. F. (1985). Effect of temperature on bacterial species diversity in thermophilic waste composting. Applied and Environmental Microbiology, 50: 899905.

Taiwo, L. and Oso, B. (2004). Influence of Composting techniques on microbial succession, temperature and $\mathrm{PH}$ in a composting municipal solid waste. Afri.J.Biotech:3:239-243.

Vashi, E. and Shah, N. (2003). Co-composting of municipal solid waste with sewage sludge -An integrated approach. Bombay, India.

Warman, P. and Termeer, W. (1996). Composting and evaluation of racetrack manure, grass Clippings and sewage sludge. Bioresource Technology, 55: 95-101. 
Table 1 Proportion of coffee by-products and each organic residue (Cow dung, leaf of Millettia ferruginea, effective microorganism (EM) in compost heap

\begin{tabular}{|l|c|c|c|c|c|}
\hline \multirow{2}{*}{ Pile type } & \multicolumn{5}{|c|}{ Treatment } \\
\cline { 2 - 6 } & 1 (control) & 2 & 3 & 4 & 5 \\
\hline Coffee pulp & $60 \%$ & $60 \%$ & $60 \%$ & $60 \%$ & $60 \%$ \\
\hline Coffee husk & $30 \%$ & $30 \%$ & $30 \%$ & $30 \%$ & $30 \%$ \\
\hline Cow dung & - & $20 \%$ & - & $20 \%$ & - \\
\hline Leaf of Millettia ferruginea & - & - & $10 \%$ & $10 \%$ & - \\
\hline Effective microorganism & - & - & - & - & 17 liter \\
\hline Top soil & $10 \%$ & $10 \%$ & $10 \%$ & $10 \%$ & $10 \%$ \\
\hline
\end{tabular}

\begin{tabular}{|c|c|c|c|c|c|c|c|c|}
\hline \multirow[t]{2}{*}{ Compost } & \multicolumn{8}{|c|}{ Mean } \\
\hline & $\mathrm{T}\left({ }^{0} \mathrm{C}\right)$ & $\mathrm{pH}$ & $\begin{array}{c}\text { CEC } \\
(\mathrm{meq} / 100 \mathrm{~g})\end{array}$ & $\begin{array}{l}\mathrm{TN} \\
(\%)\end{array}$ & $\begin{array}{c}\mathrm{AP} \\
(\mathrm{ppm})\end{array}$ & $\begin{array}{c}\text { EK } \\
(\mathrm{meq} / 100 \mathrm{~g})\end{array}$ & $\begin{array}{l}\text { OM } \\
(\%)\end{array}$ & $\begin{array}{l}\mathrm{C} / \mathrm{N} \\
(\%)\end{array}$ \\
\hline $\mathrm{T} 1$ & $36^{b}$ & $8.403^{\mathrm{ab}}$ & $47.05^{\mathrm{c}}$ & $1.061^{\mathrm{c}}$ & $135.16^{\mathrm{c}}$ & $1.34^{\mathrm{d}}$ & $36.85^{\mathrm{a}}$ & $19.25^{\mathrm{a}}$ \\
\hline $\mathrm{T} 2$ & $40.55^{\mathrm{ab}}$ & $8.384^{\mathrm{b}}$ & $57.04^{\mathrm{ab}}$ & $1.254^{\mathrm{b}}$ & $225.07^{\mathrm{a}}$ & $1.69^{b}$ & $31.33^{b}$ & $13.72^{b}$ \\
\hline $\mathrm{T} 3$ & $41^{\mathrm{a}}$ & $8.418^{\mathrm{a}}$ & $53.71^{\mathrm{b}}$ & $1.36^{\mathrm{a}}$ & $172.04^{b}$ & $1.83^{\mathrm{a}}$ & $32.87^{\mathrm{b}}$ & $13.34^{\mathrm{b}}$ \\
\hline $\mathrm{T} 4$ & $43.2^{\mathrm{a}}$ & $8.397^{\mathrm{ab}}$ & $59.33^{\mathrm{a}}$ & $1.431^{\mathrm{a}}$ & $226.99^{\mathrm{a}}$ & $1.90^{\mathrm{a}}$ & $31.46^{\mathrm{b}}$ & $11.96^{\mathrm{c}}$ \\
\hline T5 & $40^{\mathrm{ab}}$ & $8.318^{c}$ & $56.21^{\mathrm{ab}}$ & $1.243^{\mathrm{b}}$ & $184.04^{b}$ & $1.57^{\mathrm{c}}$ & $30.68^{b}$ & $13.60^{\mathrm{b}}$ \\
\hline $\operatorname{LCD}(5 \%)$ & 5.086 & 0.0328 & 3.52 & 0.0978 & 30.78 & 0.092 & 2.88 & 1.228 \\
\hline CV (\%) & 9.23 & 0.28 & 4.69 & 5.606 & 11.88 & 4.02 & 6.42 & 6.22 \\
\hline
\end{tabular}

Table 2 Physico-chemical property of different compost during composting

Table 3 Physico-chemical property at different time of composting

\section{Mean value}

\begin{tabular}{lccccccccccc}
\hline Time & $\mathrm{T}^{0}$ & $\mathrm{MC}$ & $\mathrm{pH}$ & $\mathrm{CEC}$ & $\mathrm{TN}$ & $\mathrm{AP}$ & $\mathrm{EX} . \mathrm{K}$ & $\mathrm{OM}$ & $\mathrm{OC}$ & $\mathrm{C}: \mathrm{N}$ \\
\hline $\mathrm{D} 25$ & $44.93^{\mathrm{a}}$ & $61.1^{\mathrm{a}}$ & $8.28^{\mathrm{C}}$ & $50.3^{\mathrm{c}}$ & $1.45^{\mathrm{a}}$ & $167.1^{\mathrm{b}}$ & $1.55^{\mathrm{c}}$ & $42.9^{\mathrm{a}}$ & $23.99^{\mathrm{a}}$ & $16.82^{\mathrm{a}}$ \\
$\mathrm{D} 45$ & $45.067^{\mathrm{a}}$ & $54.3^{\mathrm{b}}$ & $8.44^{\mathrm{a}}$ & $54.7^{\mathrm{b}}$ & $1.21^{\mathrm{b}}$ & $192.9^{\mathrm{a}}$ & $1.79^{\mathrm{a}}$ & $31.41^{\mathrm{b}}$ & $17.55^{\mathrm{b}}$ & $14.77^{\mathrm{b}}$ \\
$\mathrm{D} 70$ & $30.267^{\mathrm{b}}$ & $54^{\mathrm{b}}$ & $8.41^{\mathrm{b}}$ & $58.9^{\mathrm{a}}$ & $1.15^{\mathrm{b}}$ & $205.9^{\mathrm{a}}$ & $1.65^{\mathrm{b}}$ & $23.56^{\mathrm{c}}$ & $13.05^{\mathrm{c}}$ & $11.52^{\mathrm{c}}$ \\
LCD $(5 \%)$ & 3.34 & 1.44 & 0.02 & 2.3 & 0.064 & 20.24 & 0.06 & 1.9 & 1.09 & 0.8 \\
$\mathrm{CV}(\%)$ & 9.23 & 2.82 & 0.28 & 4.49 & 5.6 & 11.87 & 4.02 & 6.42 & 6.62 & 6.22 \\
\hline
\end{tabular}

Where: D25 $=25$ day of composting, D45 $=45$ day of composting, D75= 70 day of composting Means with different letter are significantly different Means with the same letters are not significantly different 